\title{
Energy Expenditure, Lipolysis, and Glucose Production in Preterm Infants Treated with Theophylline
}

\author{
CARLA R. FJELD, F. SESSIONS COLE, AND DENNIS M. BIER \\ Washington University School of Medicine, Department of Pediatrics, St. Louis, Missouri 63110
}

\begin{abstract}
Theophylline is administered to preterm infants with pulmonary disease to improve pulmonary function and reduce apneic episodes. Because it potentially mediates both $\alpha$ - and $\beta$-receptor-effector mechanisms, we tested the hypothesis that it increases lipolysis, gluconeogenesis from glycerol, and energy expenditure in 16 preterm infants, eight of whom were treated therapeutically with theophylline for apnea of prematurity ( $T$ ) and eight of whom were controls $(C)$. Mean \pm SD postnatal ages were $4.8 \pm 1.9$ wk $(\mathrm{T})$ and $2.4 \pm 0.9$ wk $(\mathrm{C})(p<0.01)$. Corrected gestational ages were $35 \pm 1.6 \mathrm{wk}(\mathrm{T})$ and $34 \pm$ 0.5 wk (C) $(p=N S)$. Body weights were $1.69 \pm 0.13 \mathrm{~kg}$ (T) and $1.70 \pm 0.23 \mathrm{~kg}(\mathrm{C})(p=\mathrm{NS})$. All infants were clinically stable, breathing room air, fed enterally, and receiving no diuretics, steroids, or antibiotics. Lipolysis, hepatic glucose production, and gluconeogenesis from glycerol were measured using $\left[2-{ }^{13} \mathrm{C}\right]$ glycerol and $\left[6,6-{ }^{3} \mathbf{H}^{2}\right]$ glucose tracers. Body water and energy expenditure were measured by the ${ }^{2} \mathrm{H}_{2}{ }^{18} \mathrm{O}$ method. Body water volumes were $68.5 \pm 3.4 \%$ body weight $(\mathrm{T})$ and $70.2 \pm 3.4 \%(\mathrm{C})(p=$ NS), suggesting fat was $10-13 \%$ of body weight in both groups. Mean daily energy expenditure was $65 \pm 22 \mathrm{kcal} /$ $\mathrm{kg}$ body weight/d (T) versus $59 \pm 5 \mathrm{kcal} / \mathrm{kg}$ body weight $/ \mathrm{d}$ (C) $(p=N S)$. Between 4 and $6 \mathrm{~h}$ after a feeding, glucose production rates were $40.5 \pm 4.3 \mu \mathrm{mol} / \mathrm{kg} / \mathrm{min}(\mathrm{T})$ and 37.6 $\pm 4.8 \mu \mathrm{mol} / \mathrm{kg} / \mathrm{min}(\mathrm{C})(p=\mathrm{NS})$. Plasma glycerol appearance rate, an index of lipolysis, was nearly equivalent in both groups, averaging $9.6 \pm 2 \mu \mathrm{mol} / \mathrm{kg} / \mathrm{min}(\mathrm{T})$ and $9.3 \pm$ $2.4 \mu \mathrm{mol} / \mathrm{kg} / \mathrm{min}(\mathrm{C})$. Glycerol accounted for $10 \pm 2 \%$ (T) and $10 \pm 4 \%(C)$ of new glucose carbon $(p=N S)$. We conclude that energy expenditure, body composition, lipolysis, glucose production, and gluconeogenesis from glycerol are not altered in preterm infants with apnea of prematurity treated therapeutically with theophylline, and therefore speculate that theophylline treatment is not a major deterrent of weight gain in premature infants with lung disease. The data suggest further that lipid mobilization may already be stimulated maximally 4 to $6 \mathrm{~h}$ after the last feeding in preterm infants studied 1 mo after birth. (Pediatr Res 32: 693-698, 1992)
\end{abstract}

Abbreviations

GCMS, gas chromatography/mass spectrometry

Received May 4, 1992; accepted August 3, 1992

Correspondence: Carla R. Fjeld, PH.D., Washington University School of Medicine, Department of Pediatrics, $660 \mathrm{~S}$. Euclid Ave., Box 8127, St. Louis, MO 63110.

Supported in part by NIH Grants RR0538928, RR00954, RR06021, and HD20805, and by Ross Laboratories and Mead Johnson.
Theophylline is a xanthine derivative bronchodilator administered in neonatal intensive care units to the majority of premature infants with apnea and/or respiratory disease. Its pharmacologic effects include relaxation of the bronchial smooth muscle (1), stimulation of the hypoxic ventilatory drive, increased minute ventilation, increased diaphragmatic contractility (2), decreased end-tidal $\mathrm{PCO}_{2}$ (1), and a reduced requirement for mechanical ventilation. It has several metabolic effects that could potentially mediate fuel kinetics, energy storage, and growth in preterm infants, including stimulating thermogenesis (3), increasing plasma glucose concentration (4), and augmenting lipolysis (5) with concomitant increases in circulating FFA concentrations and in FFA oxidation $(3,5-8)$.

In vitro, theophylline inhibits cAMP phosphodiesterase and increases intracellular cAMP and fuel mobilization (9). This mechanism, however, requires $300 \mu \mathrm{M}$ theophylline (5), which is three to ten times concentrations maintained clinically. Furthermore, therapeutic doses of theophylline increased diaphragmatic contractility without increasing intracellular concentrations of cAMP in rats (2).

Therapeutic doses $(5-6 \mu \mathrm{g} / \mathrm{mL}$, approximately $30 \mu \mathrm{M})$ increase plasma norepinephrine (3) and/or epinephrine (7). Toxic doses to canines produced hypokalemia, hypophosphatemia, hyperglycemia, and increased concentrations of epinephrine and norepinephrine $(10,11)$. These observations and the fact that the effects in canines were prevented or reversed by propranolol (10, 12) imply mediation by $\beta$-adrenergic receptor-effector mechanisms.

Theophylline also is an adenosine receptor antagonist. Peters et al. (5) recently reported that theophylline $(30 \mu \mathrm{M})$ increased lipolysis during fasting. These effects occurred without concomitant increases in circulating catecholamine concentrations, plasma glucose, insulin, or growth hormone.

In preterm infants, theophylline increased energy expenditure without altering respiratory exchange ratios (13), suggesting that the increased rate of energy expenditure was unaccompanied by alterations in the ratios of substrates oxidized to meet increased fuel requirements. However, it is also known that lipolysis can increase without detectable alterations in fuel oxidation ratios (14). Alterations in the kinetics of fuel mobilization secondary to therapeutic doses of theophylline have not been measured in preterm infants, but may be of potential physiologic and clinical importance because the preterm infant's fat and energy reserves are less developed than those of term infants and are more difficult to achieve and maintain. Mechanisms that regulate fatty acid transport are intact in newborn term infants (15). Thus, increases in lipolytic rates by theophylline could generate increased fuel supplies for oxidation. Because similar data are lacking for the preterm infant, we tested the hypothesis that rates of lipolysis, hepatic glucose production, gluconeogenesis (from glycerol), and energy expenditure are increased secondary to treatment with theophylline for apnea of prematurity in preterm infants at 2 to $7 \mathrm{wk}$ of postnatal life. 


\section{MATERIALS AND METHODS}

Subjects. Sixteen appropriate for gestational age preterm infants were recruited from the neonatal intensive care unit and assigned to either the theophylline treatment group or to the control group according to whether or not they were medicated with theophylline for apnea of prematurity, which was the only entry criterion distinguishing the two groups. Control infants were free of apnea during the study. Decisions to prescribe theophylline for symptoms of apnea were made independently from the study by a nonparticipating physician. Apnea was defined as cessation of breathing for $\geq 15$ to $20 \mathrm{~s}$, detected by chest plethysmography and bradycardia ( $<100$ beats/min). Known causes of apnea apart from prematurity had been ruled out. Theophylline was administered as an oral solution, $80 \mathrm{mg} /$ $15 \mathrm{~mL}$ (Roxane Laboratories, Inc., Columbus, $\mathrm{OH}$ ) at doses of 2 to $4 \mathrm{mg} / \mathrm{kg}$ every $8 \mathrm{~h}$ with feedings throughout the study. Doses per kg body weight were maintained during the study. At entry, all infants had an estimated gestational age by Dubowitz score of 27 to $32 \mathrm{wk}$, were between 1.5 and $2 \mathrm{~kg}$ in body weight, were fed enterally $\geq 100 \mathrm{kcal} / \mathrm{kg} / \mathrm{d}$, were clinically stable, breathing room air, without evidence of infection, and were not receiving steroid or diuretic medications. Infants were kept either in servocontrolled isolettes set to a skin temperature of 36.2 to $36.5^{\circ} \mathrm{C}$ or in open-air cribs. Infants in open-air cribs had stable body temperatures for at least $48 \mathrm{~h}$ before the study. All infants were fed every 3 to $4 \mathrm{~h}$ with Similac (Ross Laboratories, Columbus, $\mathrm{OH}$ ) or Enfamil Preterm Formula 20 or 24 (Mead-Johnson, Evansville, IN) and had been gaining weight consistently for at least $3 \mathrm{~d}$ before the study (range, $8-25 \mathrm{~g} / \mathrm{kg} / \mathrm{d}$ ). Eight infants treated with theophylline and eight control infants completed the study. ${ }^{2} \mathrm{H}_{2}{ }^{18} \mathrm{O}$ data are unavailable for one theophyllinetreated infant and two control infants because baseline or postdose urine samples were not obtained. Two other infants did not complete the infusion protocol.

The protocol was approved by the Washington University School of Medicine Human Studies Committee, and signed informed consents were obtained from the parents of all infants.

Study protocol. The studies were performed in the neonatal intensive care unit (St. Louis Children's Hospital, Washington University, St. Louis, MO) or in the special care nursery (Barnes Hospital, Washington University) during 7 continuous d. Body water was measured on d 1; energy expenditure was measured between $\mathrm{d} 1$ and 7; and lipolysis, glucose production, and the glycogenic contribution from glycerol were measured on $\mathrm{d} 7$ as described below.

On $\mathrm{d} 1,3 \mathrm{~h}$ after the previous feeding and after a urine sample for measurement of natural isotopic abundances was obtained, an accurately weighed solution that delivered approximately 0.2 $\mathrm{g}{ }^{2} \mathrm{H}_{2} \mathrm{O} / \mathrm{kg}$ body weight (as 99.9 atom $\%{ }^{2} \mathrm{H}$, MSD Isotopes, St. Louis, MO) and $0.45 \mathrm{~g} \mathrm{H}_{2}{ }^{18} \mathrm{O} / \mathrm{kg}$ body weight (as 10 or 15 atom $\%{ }^{18} \mathrm{O}$, Cambridge Isotope Laboratories, Woburn, MA) was administered orally or nasogastrically. Urine samples were obtained daily from d 1 to 7 in all infants, kept frozen at $-20^{\circ} \mathrm{C}$, and used to measure isotope dilution spaces and isotope elimination rates from which body water volume, $\mathrm{CO}_{2}$ production, and energy expenditure were calculated according to the doubly labeled water method $(16,17)$. To minimize inaccuracies in calculated isotope elimination rates (18), each infant's formula was taken from a single lot.

On $\mathrm{d} 7,\left[2-{ }^{13} \mathrm{C}\right]$ glycerol (99 atom $\%{ }^{13} \mathrm{C}, \mathrm{MSD}$ Isotopes) and $\left[6,6-{ }^{2} \mathrm{H}_{2}\right]$ glucose (98.6 atom $\%{ }^{2} \mathrm{H}$, MSD Isotopes) were infused to measure rates of hepatic glucose production, lipolysis, and gluconeogenesis from glycerol. To prepare the infusate materials, the tracers were mixed with $0.5 \mathrm{~N}$ saline, passed through $0.22-$ $\mu \mathrm{m}$ Millipore filters (Millipore Products, Bedford, MA), and stored in single-use septum-sealed vials for subsequent infusion and measurement of glycerol and glucose kinetics. The infusate was pyrogen-free, as shown by standard rabbit body temperature measurements after i.v. administration in a licensed commercial laboratory according to federal guidelines. In preparation for the tracer infusions in the infants, a needle was inserted into a peripheral vein $2 \mathrm{~h}$ after a feeding, and $1 \mathrm{~h}$ before the start of the infusion, except in one theophylline-treated infant, discussed below. The i.v. line was kept patent by infusing normal saline at $5 \mathrm{~mL} / \mathrm{h}$. Heparin was not used for this purpose. Sixty min after inserting the needle, the heel was warmed for a minimum of 5 min and a baseline blood sample of 0.5 to $0.6 \mathrm{~mL}$ was obtained by heel stick for determination of theophylline concentration, glucose concentration, and the natural abundance of ${ }^{13} \mathrm{C}$ in glucose and glycerol. The isotopes were infused continuously by means of a calibrated Harvard syringe pump (Harvard Apparatus Co., Inc., So. Natick, MA) starting $175 \pm 27$ min after the previous feeding (range, 170-200 $\mathrm{min}$ ) for $180 \mathrm{~min}$. In one theophylline-treated infant, the i.v. line was inserted at the completion of a feeding, and the infusion was started at $85 \mathrm{~min}$ from the previous feeding. In all infants, the average rate of glycerol infusion was $0.32 \pm 0.02 \mu \mathrm{mol} / \mathrm{kg} / \mathrm{min}$, and the glucose was infused at an average rate of $0.22 \pm 0.01 \mu \mathrm{mol} / \mathrm{kg} / \mathrm{min}$. Exact infusion rates for each infant were determined from the calibrated pump rates and the measured isotope concentrations in the infusate material. Blood samples $(0.3-0.4 \mathrm{~mL}$ each) were drawn at 20-min intervals beginning $60 \mathrm{~min}$ after the start of the isotopic infusions; the serum was separated and frozen at $-80^{\circ} \mathrm{C}$. The total amount of blood drawn did not exceed $5 \%$ of the estimated blood volume $(85 \mathrm{~mL} / \mathrm{kg})$. Infants remained in their isolettes, usually asleep. Infants were not fed during the infusion study; blood sugar levels were monitored periodically at the bedside to confirm normoglycemia. $\left[1,1,2,3,3{ }^{2} \mathrm{H}_{5}\right]$ glycerol (Tracer Technologies, Somerville, MA) was added to plasma samples as an internal standard for measurement of glycerol concentrations, as described below.

For measurement of theophylline concentrations, plasma was drawn between 7 and $8 \mathrm{~h}$ after theophylline administration on various days during the study. All children had theophylline measured on the day of the infusion study. Theophylline was measured from one to three additional times between the first and last days of the study according to whether blood was needed for clinical determinations. Theophylline concentrations were measured in the clinical laboratory using the Kodak Ektachem method (19). Caloric intake was determined from formula composition and volumes consumed.

Analytical Methods. Isotope ratio mass spectrometric analysis of ${ }^{2} \mathrm{H}$ and ${ }^{18} \mathrm{O}$. For measurement of ${ }^{2} \mathrm{H}$ enrichment, $5 \mu \mathrm{L}$ of urine or of the dose water or standards were cryogenically distilled into reaction vials containing $100 \mathrm{mg}$ of zinc (Friends of Biogeochemistry, Indiana University Foundation, Bloomington, IN). The vials were then heated to $600^{\circ} \mathrm{C}$ and kept isothermal for $5 \mathrm{~min}$. For measurement of ${ }^{18} \mathrm{O}$ enrichment, $1 \mathrm{~mL}$ of urine or of the dose water or standards was equilibrated with $\mathrm{CO}_{2}$ at $25^{\circ} \mathrm{C}$ for $24 \mathrm{~h}$. Isotopic ratios in hydrogen gas and in $\mathrm{CO}_{2}$ were measured using a dual-inlet mass spectrometer (VG Sira Series II), using hydrogen gas or $\mathrm{CO}_{2}$ calibrated against standard mean ocean water obtained from the National Bureau of Standards. The precision, estimated from the coefficient of variation from repeated analyses of calibration standards, was $<1 \%$ for ${ }^{18} \mathrm{O},<4 \%$ for unenriched ${ }^{2} \mathrm{H}$, and $1 \%$ for samples enriched with ${ }^{2} \mathrm{H}$.

Mass spectrometric analysis of glycerol and glucose. ${ }^{2} \mathrm{H}$ and ${ }^{13} \mathrm{C}$ abundance in glucose and glycerol was measured by standard GCMS methods $(15,20,21)$. One hundred $\mu \mathrm{L}$ of plasma were combined with $10 \mathrm{nmol}$ of $\left[1,1,2,3,3{ }^{2} \mathrm{H}_{5}\right]$ glycerol internal standard for measurement of plasma glycerol concentrations. Samples were chilled and $0.4 \mathrm{~mL}$ of $\mathrm{Ba}(\mathrm{OH})_{2}$ and $0.4 \mathrm{~mL}$ of $\mathrm{ZnSO}_{4}$ were added to precipitate the proteins. Samples were centrifuged at $6000 \mathrm{rpm}$ for $10 \mathrm{~min}$ at $0^{\circ} \mathrm{C}$, the supernatant was decanted, and the liquid was evaporated under nitrogen. The pentaacetate derivative of glucose and the triacetate derivative of glycerol were prepared by adding $40 \mu \mathrm{L}$ of a $1: 1$ volume mixture of acetic anhydride and pyridine to the dried eluates. The reaction mixtures were incubated at room temperature for 12 to $15 \mathrm{~h}$. Selected 
ion monitoring GCMS of the glycerol and glucose molecular ion clusters $(\mathrm{m} / \mathrm{z} 159,160,164$ in glycerol and $\mathrm{m} / \mathrm{z} 331,332$, and 333 in glucose) was performed on a Finnigan gas chromatograph/ mass spectrometer (model 3300).

Resolution of the glucose pentaacetate derivative was achieved using a $2 \mathrm{~m} \times 2 \mathrm{~mm}$ glass column packed with $3 \%$ OV $101-$ mesh 100/200 packing material (Applied Sciences Laboratories, Inc., State College, PA). The column was maintained at 210 to $220^{\circ} \mathrm{C}$ during analysis, and isotopic enrichment was measured by analysis of the $\mathrm{m} / \mathrm{z} 331$ reflecting unlabeled glucose, the $\mathrm{M}+$ 1 ion cluster $\left(\mathrm{m} / \mathrm{z} 332\right.$ reflecting ${ }^{13} \mathrm{C}$-glucose production from glycerol), and the $M+2$ ion cluster ( $\mathrm{m} / \mathrm{z} 333$ reflecting infused dideuterated glucose) after correcting for natural ${ }^{13} \mathrm{C}$ and ${ }^{2} \mathrm{H}$ abundance.

Resolution of the glycerol triacetate derivative was achieved using a $2 \mathrm{~m} \times 2 \mathrm{~mm}$ glass column packed with $3 \% \mathrm{OV}-17$ Supelcoport (Supelco, Inc., Bellefonte, PA) and was maintained at $130^{\circ} \mathrm{C}$. Isotopic enrichments were measured by GCMS analysis of the $\mathrm{m} / \mathrm{z} 159$ reflecting unlabeled glycerol, its corresponding $\mathrm{M}+1$ ion cluster (m/z 160 reflecting ${ }^{13} \mathrm{C}$-labeled glycerol), and $M+5$ ion cluster $(\mathrm{m} / \mathrm{z} 164$ reflecting the deuterated internal standard), after making corrections for natural ${ }^{13} \mathrm{C}$ abundance.

Rates of glucose production from glycerol were calculated from the single ${ }^{13} \mathrm{C}$ contribution to the $\mathrm{M}+1$ ion $(\mathrm{m} / \mathrm{z} 332)$ after appropriate corrections for natural isotopic contributions from unlabeled substrate and for ${ }^{2} \mathrm{H}_{2}$-labeled glucose in the infusate, using standard curves of known isotopic content (15).

Glucose concentrations were measured in each plasma sample using the conventional glucose oxidase method implemented on the Beckman Glucose Analyzer (Beckman Inc., Fullerton, CA).

Calculations. For the ${ }^{2} \mathrm{H}_{2}{ }^{18} \mathrm{O}$ doubly labeled water method, the zero-time intercepts of the plot of natural logarithmic enrichments of ${ }^{2} \mathrm{H}$ and ${ }^{18} \mathrm{O}(y)$ versus time post-dose $(x)$ were used to calculate isotope elimination rates and isotope dilution spaces. Total body water was calculated from mean dilution spaces [i.e. $\left.\left({ }^{2} \mathrm{H}+{ }^{18} \mathrm{O}\right) / 2\right]$, assuming ${ }^{2} \mathrm{H}$ overestimates body water by $4 \%$ and that ${ }^{18} \mathrm{O}$ overestimates body water by $1 \%(17)$. Fat-free mass was estimated from the mean body water volume calculated from dilution of both isotopes for each subject, assuming the hydration coefficient of fat-free mass for infants 1 to 2 mo postnatally is $78.3 \%$ (22). Rates of $\mathrm{CO}_{2}$ production were calculated as described $(16,17)$. Oxygen consumption was calculated assuming a respiratory exchange ratio of 0.91 , derived from published studies of growing preterm infants (23-26). Caloric equivalents of $\mathrm{CO}_{2}$ were calculated using Weir's equation (27): Energy expenditure $(\mathrm{kcal} / \mathrm{d})=3.941 \mathrm{O}_{2}(\mathrm{~L})+1.106 \mathrm{CO}_{2}(\mathrm{~L})$, which gave an average caloric equivalent of $\mathrm{CO}_{2}$ of $121.7 \mathrm{kcal} / \mathrm{mol}$.

Glycerol concentrations and glycerol and glucose kinetics were calculated as described $(15,20,21)$. Briefly, plasma glycerol concentration was calculated from $159 / 164$ ion current ratios and $\left[1,1,2,3,3{ }^{2} \mathrm{H}_{5}\right]$ glycerol standards. Glycerol and glucose flux and the percentage of glucose derived from glycerol were calculated by conventional steady-state tracer dilution equations (15) using enrichments obtained between 100 and $180 \mathrm{~min}$ [SD/ mean $<0.10$ and 0.08 for $\left[{ }^{13} \mathrm{C}\right]$ glycerol $(\mathrm{m} / \mathrm{z} 160 / 159)$ and $\left[{ }^{2} \mathrm{H}_{2}\right]$ glucose $(\mathrm{m} / \mathrm{z} 333 / 331)$, respectively]. Glucose derived from glycerol was calculated from the ${ }^{13} \mathrm{C}$-glucose enrichments at $180 \mathrm{~min}$. The average coefficients of variation of the individual subjects' plasma glycerol concentrations between 100 and 180 min were $5 \pm 2 \%$ in theophylline-treated and $9 \pm 6 \%$ in control infants. These values were not statistically different and support attainment of substrate steady state during the period of kinetic analysis.

Statistical analysis. Data are presented as means \pm SD unless otherwise stated. Means and data from correlation analyses were compared using $t$ tests. The Mann-Whitney test for differences between means was applied to the energy expenditure data because the data were highly skewed by one individual. An effect of caloric intake during the $7 \mathrm{~d}$ preceding the study on glycerol flux was tested using analysis of variance. Differences were considered significant at $p<0.05$.

\section{RESULTS}

Clinical characteristics. Selected clinical characteristics are shown in Table 1. By Dubowitz score, the estimated gestational age at birth of the theophylline-treated infants $(30 \pm 2 \mathrm{wk})$ was significantly younger than of the control infants $(32 \pm 1 \mathrm{wk})(p$ $<0.001$ ). However, corrected gestational ages (estimated gestational age plus postnatal age) on study d 1 were comparable, averaging $36 \pm 2$ in theophylline-treated and $35 \pm 1 \mathrm{wk}$ in control infants, respectively. Neither mean birth weight (1295 \pm $366 \mathrm{~g}$ versus $1547 \pm 210 \mathrm{~g}$, respectively), mean body weight on $\mathrm{d} 1$ of the study $(1686 \pm 128$ versus $1703 \pm 231 \mathrm{~g}$, respectively), nor body weight on the day of the infusion studies $(1898 \pm 124$ versus $1917 \pm 247 \mathrm{~g}$, respectively) differed statistically. Body water (Table 2) was $68.5 \pm 3.4 \%$ of body weight in the theophylline-treated infants and $70.2 \pm 3.4 \%$ of body weight in the control infants $(p=\mathrm{NS})$. Based on an estimate of $78.3 \%$ hydration of the fat-free compartment in infants at 1 to $2 \mathrm{mo}$ of postnatal life (22), the average fat percentage of body weight was estimated as $10 \%$ in theophylline-treated and $13 \%$ in control infants.

Mean plasma theophylline level in theophylline-treated infants was $8 \pm 1 \mu \mathrm{g} / \mathrm{mL}$ (range, $5-12 \mu \mathrm{g} / \mathrm{mL}$, equivalent to $28-67 \mu \mathrm{M}$ ), which is within the therapeutic range. There was no clinical evidence of theophylline toxicity.

Mean caloric intake during $7 \mathrm{~d}$ immediately before the study was not significantly different between groups $(118 \pm 15 \mathrm{kcal} /$ $\mathrm{kg} / \mathrm{d}$ in theophylline-treated infants and $134 \pm 21 \mathrm{kcal} / \mathrm{kg} / \mathrm{d}$ in control infants), nor was caloric intake during the doubly labeled water study significantly different $(121 \pm 11$ versus $131 \pm 18$

Table 1. Selected clinical characteristics*

\begin{tabular}{lccc}
\hline & $\begin{array}{c}\text { Theophylline- } \\
\text { treated } \\
(n=8)\end{array}$ & $\begin{array}{c}\text { Controls } \\
(n=8)\end{array}$ & $p$ \\
& $30 \pm 1.6$ & $32 \pm 0.9$ & $<0.01$ \\
& $34 \pm 13.3$ & $17 \pm 6.1$ & $<0.001$ \\
Gestational age (wk) & $35 \pm 1.6$ & $34 \pm 0.5$ & NS \\
Postnatal age (d) & & & \\
Corrected gestational age & & & \\
$\quad(w k) \dagger$ & $1.30 \pm 0.37$ & $1.55 \pm 0.21$ & NS \\
Birth wt (kg) & & & \\
Study wt $(\mathrm{kg})$ & $1.69 \pm 0.13$ & $1.70 \pm 0.23$ & $\mathrm{NS}$ \\
$\quad$ Entry day & $1.90 \pm 0.12$ & $1.92 \pm 0.25$ & $\mathrm{NS}$ \\
$\quad$ Infusion day & $121 \pm 11$ & $131 \pm 18$ & $\mathrm{NS}$ \\
\hline Energy intake $(\mathrm{kcal} / \mathrm{kg} / \mathrm{d})$ & & & \\
\hline
\end{tabular}

$*$ Mean $\pm \mathrm{SD}$

$\dagger$ Gestational age plus postnatal age.

Table 2. Body water, isotope elimination rates, and energy expenditure in growing preterm infants

\begin{tabular}{lccc}
\hline & $\begin{array}{c}\text { Theophylline- } \\
\text { treated } \\
(n=7)\end{array}$ & $\begin{array}{c}\text { Controls } \\
(n=6)\end{array}$ & $p$ \\
\hline $\begin{array}{l}\text { Body water }(\mathrm{kg}) \\
\text { \% Body wt }\end{array}$ & $\begin{array}{c}1.217 \pm 0.135 \\
68.5 \pm 3.4\end{array}$ & $\begin{array}{c}1.298 \pm 0.139 \\
70.2 \pm 3.4\end{array}$ & $\mathrm{NS}$ \\
$\begin{array}{l}\text { Isotope dilution spaces } \\
\quad\left({ }^{2} \mathrm{H} /{ }^{18} \mathrm{O}\right)\end{array}$ & $1.032 \pm 0.019$ & $1.038 \pm 0.027$ & $\mathrm{NS}$ \\
$\begin{array}{l}\text { Isotope elimination rates } \\
{ }^{2} \mathrm{H}\left(\mathrm{k}_{\mathrm{D}}\right)^{*}\end{array}$ & $0.1934 \pm 0.0245$ & $0.2235 \pm 0.0262$ & \\
${ }^{18} \mathrm{O}\left(\mathrm{k}_{\mathrm{o}}\right) \dagger$ & $0.2301 \pm 0.0283$ & $0.2578 \pm 0.0265$ & \\
$\mathrm{CO}_{2}$ production $(\mathrm{mol} / \mathrm{d})$ & $0.953 \pm 0.34$ & $0.908 \pm 0.17$ & $\mathrm{NS}$ \\
$\begin{array}{l}\text { Energy expenditure } \\
\quad(\mathrm{kcal} / \mathrm{kg} / \mathrm{d})\end{array}$ & $65 \pm 22$ & $59 \pm 5$ & $\mathrm{NS}$ \\
\end{tabular}

* $\mathrm{k}_{\mathrm{D}}$, fractional elimination rate constant for deuterium.

$\dagger \mathrm{k}_{\mathrm{o}}$, fractional elimination rate constant for oxygen- 18 . 
$\mathrm{kcal} / \mathrm{kg} / \mathrm{d}$ in the theophylline-treated infants and control infants, respectively).

$\mathrm{CO}_{2}$ production. Isotopic dilution spaces for ${ }^{2} \mathrm{H}$ and ${ }^{18} \mathrm{O}$, body water volumes, isotope elimination rates, rates of $\mathrm{CO}_{2}$ production, and energy expenditure data are listed in Table 2. Ratios of isotope dilution spaces $\left({ }^{2} \mathrm{H} /{ }^{18} \mathrm{O}\right)$ calculated by the back-extrapolation method were $1.032 \pm 0.02$ in theophylline-treated and $1.038 \pm 0.027$ in control infants and were comparable to the ratio (1.025) that was calculated in the same way in preterm infants whose average daily weight gain was $15 \mathrm{~g} / \mathrm{kg} / \mathrm{d}(23)$. Paired comparisons of body water volumes measured by ${ }^{2} \mathrm{H}$ - and ${ }^{18} \mathrm{O}$-dilution showed no statistically significant difference in either the theophylline-treated $(p=0.803)$ or control $(p=0.554)$ infants. Mean rates of $\mathrm{CO}_{2}$ production were nearly identical in both groups, averaging $0.95 \pm 0.34 \mathrm{~mol} / \mathrm{d}$ in theophylline-treated infants and $0.91 \pm 0.17 \mathrm{~mol} / \mathrm{d}$ in control infants $(p=\mathrm{NS})$. Average daily energy expenditure was $65 \pm 22 \mathrm{kcal} / \mathrm{kg}$ body weight and $59 \pm 5 \mathrm{kcal} / \mathrm{kg}$ body weight in the respective groups ( $p=$ NS by $t$ test and Mann-Whitney comparisons because energy expenditure in one infant treated with theophylline was $127 \mathrm{kcal} / \mathrm{kg} / \mathrm{d}$, which was 2 to $3 \mathrm{SD}$ beyond the mean, which skewed the energy expenditure data in the theophylline-treated infants). Mean \pm SD energy expenditure for theophylline-treated infants without the data from this particular infant was $57 \pm 7$ $\mathrm{kcal} / \mathrm{kg} / \mathrm{d}(n=6)$. Per $\mathrm{kg}$ of fat-free mass, daily energy expenditure was $65.5 \pm 5.6 \mathrm{kcal}(n=6)$ and $66.3 \pm 5.5 \mathrm{kcal}$ in theophylline-treated infants and control infants, respectively, indicating that theophylline at therapeutic concentrations did not increase average daily energy expenditure. Further evidence for this is that individuals' plasma theophylline levels were not correlated with daily energy expenditure $(r=0.102)$.

Substrate concentrations. Baseline plasma glucose was $3.83 \pm$ $0.56 \mathrm{mM}(69 \pm 10 \mathrm{mg} / \mathrm{dL})$ in theophylline-treated infants and not statistically different from the concentration in control infants which was $4.06 \pm 0.61 \mathrm{mM}(73 \pm 11 \mathrm{mg} / \mathrm{dL})$. Between 100 and $180 \mathrm{~min}$ from the start of the infusion, equivalent to 280 through $360 \mathrm{~min}$ from the last feeding plasma glucose concentration (Table 3) was $4.16 \pm 0.50 \mathrm{mM}(75 \pm 9 \mathrm{mg} / \mathrm{dL})$ in theophylline-treated (mean coefficient of variation $=6 \%$ ) and $4.06 \pm 0.56 \mathrm{mM}(73 \pm 10 \mathrm{mg} / \mathrm{dL})$ in controls (mean coefficient of variation $=5 \%$ ), confirming normoglycemia and glucose steady state during the entire study.

Baseline plasma glycerol concentration was $107 \pm 30 \mu \mathrm{M}$ in theophylline-treated infants, statistically less than the concentration in the controls, $171 \pm 36 \mu \mathrm{M}(p=0.004)$. The basal plasma glycerol concentrations were within the range reported for newborn term and preterm infants (15) and for infants 1 to 6 mo of age (28) but were lower than concentrations reported recently in normal newborn term infants and lower than in newborn term infants of insulin-dependent diabetic mothers (29). The intersubject variability in glycerol concentration was not due to the length of time between the last feeding and the basal blood sample, inasmuch as the interval was comparable for all infants

Table 3. Concentrations and kinetics of glucose and glycerol 4 to $6 \mathrm{~h}$ after feeding

\begin{tabular}{lccc}
\hline & $\begin{array}{c}\text { Theophylline- } \\
\text { treated } \\
(n=6)\end{array}$ & $\begin{array}{c}\text { Controls } \\
(n=8)\end{array}$ & $p$ \\
\hline Plasma concentrations & $4.16 \pm 0.50$ & $4.06 \pm 0.56$ & $\mathrm{NS}$ \\
$\quad$ Glucose $(\mathrm{mM})$ & $108 \pm 30$ & $143 \pm 45$ & $\mathrm{NS}$ \\
$\quad$ Glycerol $(\mu \mathrm{M})$ & $40.5 \pm 4.3$ & $37.6 \pm 4.8$ & $\mathrm{NS}$ \\
Flux rates $(\mu \mathrm{mol} / \mathrm{kg} / \mathrm{min})$ & $9.6 \pm 2.0$ & $9.3 \pm 2.4$ & $\mathrm{NS}$ \\
$\quad$ Glucose & & & \\
$\quad$ Glycerol & $82 \pm 18$ & $81 \pm 22$ & $\mathrm{NS}$ \\
Glycerol conversion to glu- & & & \\
$\quad$ cose $(6$ h after feeding) & & & \\
$\quad$ Fraction of glycerol & $9.6 \pm 2$ & $10.4 \pm 4$ & $\mathrm{NS}$ \\
\hline Glucose from glycerol (\%) & & & \\
\hline
\end{tabular}

except one $(175 \pm 27 \mathrm{~min}$; range, $170-200 \mathrm{~min})$. In the one infant whose basal blood sample was drawn 85 min postprandially, plasma glycerol was $180 \mu \mathrm{M}$. The baseline glycerol concentration was also not a function of caloric intake in the feeding that preceded the baseline blood sample $(18 \pm 5 \mathrm{kcal} / \mathrm{kg}$; range, $14-26 \mathrm{kcal} / \mathrm{kg}$ ).

Plasma glycerol concentrations between 100 and $180 \mathrm{~min}$ from the start of the infusion, equivalent to 280 through $360 \mathrm{~min}$ from the last feeding (Table 3), were $108 \pm 30 \mu \mathrm{M}$ in theophyllinetreated infants and not statistically different from $143 \pm 45 \mu \mathrm{M}$ in controls.

Glucose production. Glucose production (Table 3) was $40.5 \pm$ $4.3 \mu \mathrm{mol} / \mathrm{kg} / \mathrm{min}(10.5 \mathrm{~g} / \mathrm{kg} / \mathrm{d})$ in theophylline-treated infants and not statistically different from the rate in controls $[37.6 \pm$ $4.8 \mu \mathrm{mol} / \mathrm{kg} / \mathrm{min}(9.7 \mathrm{~g} / \mathrm{kg} / \mathrm{d})]$. The mean glucose flux rate calculated for the two groups together $(38.8 \pm 4.7 \mu \mathrm{mol} / \mathrm{kg} /$ min), however, was statistically greater than the rates of $32.2 \pm$ $7.2 \mathrm{SD}(p=0.03)$ and $33.7 \pm 6.8 \mathrm{SD}(p=0.06) \mu \mathrm{mol} / \mathrm{kg} / \mathrm{min}$ reported previously from this laboratory for newborn term infants $(15,30)$.

Lipolysis. Four to $6 \mathrm{~h}$ after the last feeding, rates of glycerol flux, and thus of lipolysis, were $9.6 \pm 2.0 \mu \mathrm{mol} / \mathrm{kg} / \mathrm{min}$ in theophylline-treated infants and not statistically different from $9.3 \pm 2.4 \mu \mathrm{mol} / \mathrm{kg} / \mathrm{min}$ in controls (Table 3 ).

Plasma glycerol concentrations were linearly correlated with glycerol flux rates (Fig. 1) in the combined group of control and theophylline-treated preterm infants $(r=0.67 ; p<0.01)$, a finding consistent with previous observations in term newborn infants $(15,31)$.

Gluconeogenesis from glycerol. Glycerol appearing in plasma between 100 and 180 min of the infusion study $(4-6 \mathrm{~h}$ from the last feeding) was used principally to form new glucose. The percentage of plasma glycerol flux converted to glucose $6 \mathrm{~h}$ after a feeding was nearly identical in both groups, averaging $82 \pm$ $18 \%$ of glycerol turnover in theophylline-treated infants and 81 $\pm 22 \%$ in the controls. In the theophylline-treated and control infants combined, $82 \pm 19 \%$ of the plasma glycerol appearance produced was converted to glucose, which was not statistically different from the mean observed $(73 \pm 18 \%)$ in five newborn infants at steady state (15) or from $8 \overline{7} \pm 16 \%$ in six normal newborn infants (29)

Gluconeogenesis from glycerol accounted for $9.6 \pm 2 \%$ of glucose production in theophylline-treated infants at steady state, and for $10.4 \pm 4 \%$ in controls $(p=N S)$. The percentage of glucose derived from glycerol is related directly to plasma glycerol flux rates $(r=0.67 ; p<0.01)$ shown in Figure 2 .

\section{DISCUSSION}

This study demonstrates that energy expenditure and rates of lipolysis, glucose and glycerol turnover, and gluconeogenesis

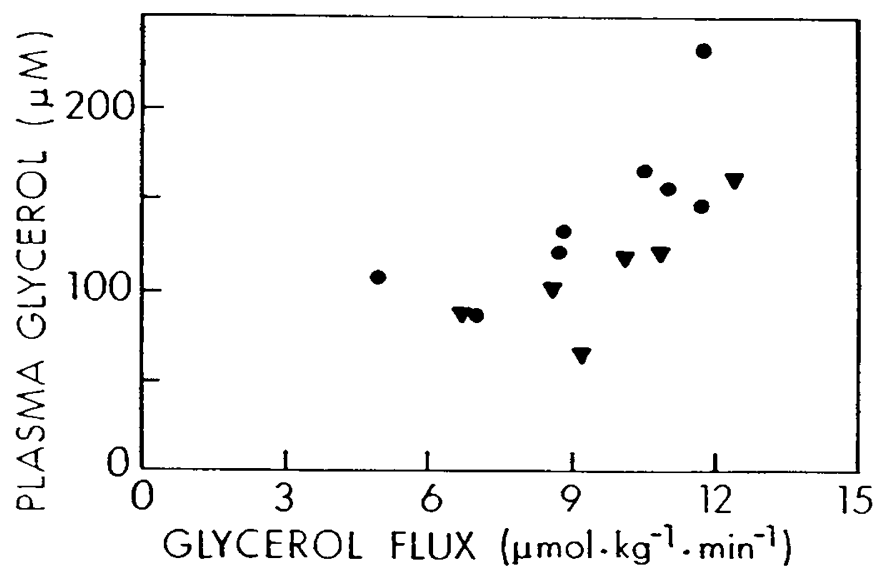

Fig. 1. Plasma glycerol and glycerol flux rates measured between 4 and $6 \mathrm{~h}$ after a feeding in preterm infants treated with theophylline ( $\mathbf{v})$ and control infants $(\bullet)(n=14 ; r=0.67 ; p<0.01)$. 


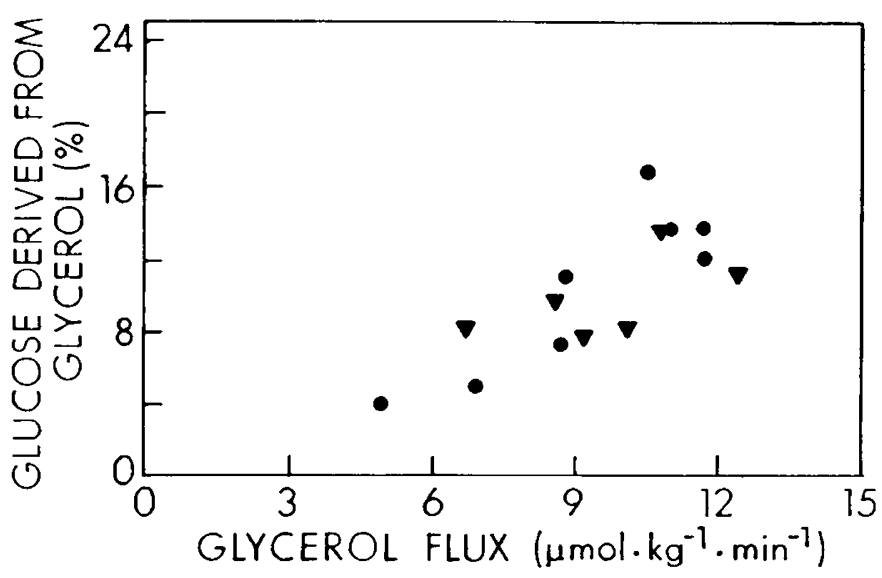

Fig. 2. Gluconeogenesis from glycerol and glycerol flux rates measured between 4 and $6 \mathrm{~h}$ after a feeding in preterm infants treated with theophylline $(\mathbf{\nabla})$ and control infants $(\bullet)(n=14 ; r=0.66 ; p<0.01)$.

from glycerol are unaltered by therapeutic concentrations of theophylline in preterm infants. This finding is at variance with one reported recently by Peters et al. (5), who found that rates of lipolysis were increased by theophylline in fasted healthy adults. The discrepancy may be due to the fact that the infants had been medicated with theophylline for an average of $34 \mathrm{~d}$ (range, 15-49 d), whereas the adults had no history of chronic theophylline exposure. This speculation is consistent with the facts that theophylline's lipolytic effect may be due to its inhibition of adenosine receptor binding and that adenosine receptor density may be increased by chronic theophylline exposure (32). If receptor density had been increased by chronic use in the preterm infants, then theophylline's adenosine antagonism and lipolytic effects may have been blunted, which could explain the variance with the adults.

Glucose production rates measured in the present study are faster than rates reported previously from this laboratory (15, $30)$. Because rates in the present study overlap the ranges measured in the previous studies and because the previously studied infants were studied at different corrected gestational ages, chronologic ages, and with use of different feeding regimens, we do not believe that these statistical differences reflect significant biologic differences.

The rate of glycerol appearance in the two groups of growing preterm infants in this study was 9 to $10 \mu \mathrm{mol} / \mathrm{kg} / \mathrm{min}$ and is faster than rates reported in normal adults (5). The issue in newborn infants is not completely settled. Bougnères et al. (15) reported rates of $4.4 \pm 1.2 \mu \mathrm{mol} / \mathrm{kg} / \mathrm{min}$ in term newborn infants studied on d 1 of postnatal life. Patel and Kalhan (29) reported rates of $9.5 \pm 2$ or $9.6 \pm 2 \mu \mathrm{mol} / \mathrm{kg} / \mathrm{min}$ in appropriate for gestational age newborn term infants and infants of insulindependent diabetic mothers, respectively, studied 7 to $9 \mathrm{~h}$ after a feeding. Given the differences in postnatal age between infants in the present study and those reported earlier from our laboratory (15), we cannot conclude confidently whether lipolytic rates differ between term and preterm infants or whether postnatal age changes these rates, consistent with the observations of Marcus et al. (33), who found age-related differences in the lipolytic responses of term infants' adipocytes to thyrotropin and catecholamines. Given the rapid lipolytic rates, it is tempting to speculate that theophylline at therapeutic doses has no effect on lipolysis in preterm infants, because lipid mobilization was already maximally stimulated $6 \mathrm{~h}$ after feeding. When the data of the present study are combined with those of the two previously reported neonatal glycerol flux studies of Bougnères et al. (15) and Patel and Kalhan (29), a significant $(p<0.001)$ relationship between glycerol flux and plasma glycerol concentrations is apparent.

Because diet is one important variable that might influence the demand for hydrolysis of adipose tissue lipid stores, we analyzed the effect of dietary intake on the results described. All infants were consuming more than $100 \mathrm{kcal} / \mathrm{kg} / \mathrm{d}$ for $1 \mathrm{wk}$ before the study. Caloric intake was not regulated by the protocol, apart from the fact that a minimum intake of $100 \mathrm{kcal} / \mathrm{kg} / \mathrm{d}$ was one criterion for inclusion. Because they were also all gaining weight (mean 18, range $10-20 \mathrm{~g} / \mathrm{kg} / \mathrm{d}$ ), dietary energy intake was at least adequate. Additionally, there was no relationship of lipolysis or gluconeogenesis from glycerol to dietary energy across the intake range in this study.

We have also shown that glycerol can be a significant source of gluconeogenic carbon in preterm infants, supplying 9 to $10 \%$ of hepatic glucose production 4 to $6 \mathrm{~h}$ after a feeding (Fig. 2). The glucogenic contribution from glycerol in our preterm infants was less than the rate recently reported by Patel and Kalhan (29), who found glycerol contributed $20 \%$ of new glucose carbon in newborn term infants. Because the FFA generated from peripheral adipose tissue lipolysis are themselves crucial for maintaining an adequate gluconeogenic rate and because glycerol represented an important source of gluconeogenic carbon in these premature infants, our data confirm that an active lipolytic rate is important for maintaining normoglycemia in the preterm infants. Further, our data imply that lipid mobilization and gluconeogenesis may already be maximally stimulated in the preterm infant at this stage of development, potentially explaining the failure of theophylline to further augment these rates.

The dilution spaces of ${ }^{2} \mathrm{H}$ and ${ }^{18} \mathrm{O}$ were comparable to those measured previously in preterm infants (23). The average daily rate of energy expenditure in the present study was $63.5 \pm 5$ $\mathrm{kcal} / \mathrm{kg} / \mathrm{d}$ in infants whose metabolizable energy intake was approximately $130 \mathrm{kcal} / \mathrm{kg}$ and whose mean rate of weight gain was $18 \mathrm{~g} / \mathrm{kg} / \mathrm{d}$. Westerterp et al. (34) and Roberts et al. (23), in validations of the doubly labeled water method, and Bell et al. (35), using classic indirect calorimetry, reported comparable rates of energy expenditure. In contrast, Grant and Denne (36) reported slightly lower mean daily energy expenditure rates of 52 $\mathrm{kcal} / \mathrm{kg} / \mathrm{d}$ in intermittently fed newborn preterm infants. Their infants were fed only about $80 \%$ of the caloric intake used in the present study, however, so some of the discrepancy in measured energy expenditure is due to differences in energy intake and some to postnatal age and maturation.

We used a respiratory exchange ratio of 0.91 , based on published data from growing preterm infants (23-26). The assumption that the same respiratory exchange ratio could be used for both groups of infants is supported by our finding that rates of lipolysis were not statistically different between the groups and, by the previous finding, that the respiratory exchange ratio of premature infants was not altered by plasma theophylline in the range used in the present study (13).

Our study compared preterm infants treated with theophylline for symptoms of apnea of prematurity with untreated controls. Because there is no apparent effect of therapeutic doses of theophylline on rates of lipolysis or energy expenditure in preterm infants with apnea, it is unlikely that therapeutic doses of theophylline are responsible for growth failure in preterm infants with lung disease.

Acknowledgments. The authors thank Dale Schoeller, Lisa Fischer, R.N., the staffs of both nurseries, the Pediatric Clinical Research Center, and also Richard Berger and Mollie Freebairn for technical assistance.

\section{REFERENCES}

1. Grassi V, Boschetti E, Tantucci C 1989 Round table on antiasthmatic drugs; beta-agonists and theophylline. Eur Respir J 2(suppl):551s-555s

2. Kolbeck RC, Speir WA 1991 Theophylline, fatigue, and diaphragm contractility: cellular levels of 45-Ca and cAMP. J Appl Physiol 70:1933-1937

3. Wang LCH, Paul Man SF, Belcastro AN 1987 Metabolic and hormonal responses in theophylline-increased cold resistance in males. J Appl Physiol 63:589-596 
4. Cathcart-Rake WF Kyner JL, Azarnoff DL 1979 Metabolic responses to plasma concentration of theophylline. Clin Pharmacol Ther 26:89-95

5. Peters EJ, Klein S, Wolfe RR 1991 Effect of short-term fasting on the lipolytic response to theophylline. Am J Physiol 261:E500-E504

6. Vestal RE, Eiriksson CE, Musser B, Ozaki LK, Halter JB 1983 Effect of intravenous aminophylline on plasma levels of catecholamines and related cardiovascular and metabolic responses in man. Circulation 67:162-171

7. Atuk NO, Blaydes MC, Westervelt FB, Wood JE 1967 Effect of aminophylline on urinary excretion of epinephrine and norepinephrine in man. Circulation $35: 745-753$

8. Arnman K, Carlstrom S, Theorell J 1975 The effect of norepinephrine and theophylline on blood glucose, plasma FFA, plasma glycerol and plasma insulin in normal subjects. Acta Med Scand 197:271-274

9. Vonlanthen MG, McCarter RJ, Casto DT 1989 Metabolic effects of aminophylline in rats. Am J Physiol 256:R1274-R1278

10. Kearney TE, Manoguerra AS, Curtis GP, Ziegler MG 1985 Theophylline toxicity and the beta-adrenergic system. Ann Intern Med 102:766-769

11. Curry SC, Vance MV, Requa R, Armstead R 1985 The effects of toxic concentrations of theophylline on oxygen consumption, ventricular work, acid base balance, and plasma catecholamine levels in the dog. Ann Emerg Med 14:554-561

12. Strubelt O, Hoffmann A, Siegers CP, Sierra-Callejas JL 1976 On the pathogenesis of cardiac necrosis induced by theophylline and caffeine. Acta Pharmaco Toxicol 39:383-392

13. Milsap RL, Krauss AN, Auld PAM 1980 Oxygen consumption in apneic premature infants after low-dose theophylline. Clin Pharmacol Ther 28:536540

14. Wolfe RR, Herndon DN, Peters EJ, Jahoor F, Desai MH, Holland OF 1987 Regulation of lipolysis in severely burned children. Ann Surg 206:214-221

15. Bougnères PF, Karl IE, Hillman LS, Bier DM 1982 Lipid transport in the human newborn. Palmitate and glycerol turnover and the contribution of glycerol to neonatal hepatic glucose output. J Clin Invest 70:262-270

16. International Dietary Energy Consultancy Group 1990 The Doubly-Labelled Water Method for Measuring Energy Expenditure. Technical Recommendations for Use in Humans. International Atomic Energy Agency, Vienna

17. Schoeller DA 1988 Measurement of energy expenditure in free-living humans using doubly labeled water. J Nutr 118:1278-1289

18. Roberts SB, Coward WA, Ewing G, Savage J, Cole TJ, Lucas A 1988 Effect of weaning on accuracy of doubly labeled water method in infants. Am J Physiol 254:R622-R627

19. Lauff JJ 1987 Ion-pair high-performance liquid chromatographic procedure for the quantitative analysis of theophylline in serum samples. J Chromatogr 417:99-109

20. Bier DM, Arnold KJ, Sherman WR, Holland WH, Holmes WF, Kipnis DM
1977 In vivo measurement of glucose and alanine metabolism with stable isotopic tracers. Diabetes 26:1005-1015

21. Chiasson JL, Liljenquist JE, Lacy WW, Jennings AS, Cherrington AD 1977 Gluconeogenesis: methodological approaches in vivo. Fed Proc 36:229-235

22. Fomon SJ, Haschke F, Ziegler EE, Nelson SE 1982 Body composition of reference children from birth to age 10 years. Am J Clin Nutr 35:1169-1175

23. Roberts SB, Cowards WA, Norhia V, Schlingenseipen KH, Lucas A 1986 Comparison of the doubly labeled water $\left({ }^{2} \mathrm{H}_{2}{ }^{18} \mathrm{O}\right)$ method with indirect calorimetry and a nutrient-balance study for simultaneous determination of energy expenditure, water intake, and metabolizable energy intake in premature infants. Am J Clin Nutr 44:315-322

24. Putet G, Senterre J, Rigo J, Salle B 1984 Nutrient balance, energy utilization, and composition of weight gain in very-low-birth-weight infants fed pooled human milk or a preterm formula. J Pediatr 105:79-85

25. Reichman B, Chessex P, Verellen G, Putet G, Smith JM, Heim T, Swyer PR 1983 Dietary composition and macronutrient storage in preterm infants. Pediatrics 72:322-327

26. Gudinchet F, Schutz Y, Micheli JL, Stettler E, Jéquier E 1982 Metabolic cost of growth in very low-birth-weight infants. Pediatr Res 16:1025-1030

27. Weir JB de V 1949 New methods for calculating metabolic rate with special reference to protein metabolism. J Physiol 109:1-9

28. Persson B, Gentz J 1966 The pattern of blood lipids, glycerol and ketone bodies during the neonatal period, infancy and childhood. Acta Paediatr Scand 55:353-362

29. Patel D, Kalhan S 1992 Glycerol metabolism and triglyceride-fatty acid cycling in the human newborn: effect of maternal diabetes and intrauterine growth retardation. Pediatr Res 31:52-58

30. Bier DM, Leake RD, Haymond MW, Arnold KJ, Gruenke LD, Sperling MA, Kipnis DM 1977 Measurement of "true" glucose production rates in infancy and childhood with 6,6-dideuteroglucose. Diabetes 26:1016-1023

31. Kalhan SC, Oliven A, King KC, Lucero C 1986 Role of glucose in the regulation of endogenous glucose production in the human newborn. Pediatr Res 20:49-52

32. Lupica CR, Jarvis MF, Berman RF 1991 Chronic theophylline treatment in vivo increases high affinity adenosine $A 1$ receptor binding and sensitivity to exogenous adenosine in the in vitro hippocampal slice. Brain Res 542:55-62

33. Marcus C, Ehrén H, Bolme P, Arner P 1988 Regulation of lipolysis during the neonatal period. J Clin Invest 82:1793-1797

34. Westerterp KR, Lafeber HN, Sulkers EJ, Sauer PJJ 1991 Comparison of short term indirect calorimetry and doubly labeled water method for the assessment of energy expenditure in preterm infants. Biol Neonate 60:75-82

35. Bell EF, Rios GR, Wilmoth PK 1986 Estimation of 24-hour energy expenditure from shorter measurement periods in premature infants. Pediatr Res 20:646649

36. Grant J, Denne SC 1991 Effect of intermittent versus continuous enteral feeding on energy expenditure in premature infants. J Pediatr 118:928-932 